Transatlantic Modernism 
Also by Martin Halliwell

ROMANTIC SCIENCE AND THE EXPERIENCE OF SELF

CRITICAL HUMANISMS

IMAGES OF IDIOCY

THE CONSTANT DIALOGUE 


\section{Transatlantic Modernism}

Moral Dilemmas in Modernist Fiction

Martin Halliwell

Edinburgh University Press 
(C) Martin Halliwell, 2001, 2006

Edinburgh University Press Ltd

22 George Square, Edinburgh

First published by Palgrave 2001, as

Modernism and Morality

This paperback edition 2006

Typeset in 9/12 pt ITC Stone Serif by Servis Filmsetting Ltd, Manchester and printed and bound in Great Britain by

Antony Rowe Ltd, Chippenham, Wilts

A CIP record for this book is available from the British Library

ISBN 0748623930 (paperback)

ISBN 9781474497121 (EPDF)

The right of Martin Halliwell to be identified as author of this work has been asserted in accordance with the Copyright, Designs and Patents Act 1988. 


\section{For Laraine}

'If a story seems moral, do not believe it.'

— Tim O'Brien, The Things They Carried (1990) 
